\title{
ИСТОЧНИКОВЕДЕНИЕ
}

УДК 811.512 .37

DOI: $10.22162 / 2500-1523-2020-2-244-254$

\section{Письмо нойона Замьяна астраханскому губернатору Н. А. Бекетову о планах ухода калмыков на историческую родину}

\author{
Дарья Бадмаевна Гедеева
}

\author{
${ }^{1}$ Калмыцкий научный центр РАН (д. 8, ул. им. И. К. Илишкина, 358000 Элиста, \\ Российская Федерация) \\ кандидат филологических наук, ведущий научный сотрудник \\ (iD 0000-0002-8735-9184. E-mail: dgedeeva@mail.ru \\ (c) КалмНЦ РАН, 2020 \\ С Гедеева Д. Б., 2020
}

\begin{abstract}
Аннотация. Введение. В статье вводится в научный оборот архивный документ XVIII в., представляющий собой письмо калмыцкого нойона Замьяна астраханскому губернатору Н. А. Бекетову. Материалом статьи послужил архивный документ из фонда И-36 Национального архива Республики Калмыкия. Результатыл. В письме содержится важная информация, отражающая настроения калмыцкой знати накануне ухода большей части калмыцкого народа в 1771 г. на историческую родину. Находясь в окружении народов, имеющих чуждые им веру, язык и традиции, калмыки всегда помнили о своих азиатских корнях, и их не покидала мысль о возвращении. Это желание все более укреплялось в результате колонизаторской политики российского государства. Однако не всем хотелось уходить с нажитого места, отправляться в опасный путь, в неизвестное будущее. К числу таких людей относился нойон Замьян. Его письмо губернатору пронизано беспокойством и желанием остановить уход калмыков с помощью российской власти. Вместе с тем Замьян объясняет губернатору причины, по которым народ хочет уйти из России. Этот интересный по исторической информации документ является также и ценным лингвистическим источником, предоставляющим материал о калмыцком языке второй половины XVIII в. Цель статьи - ввести в научный оборот калмыцкий текст письма и его русский перевод указанного периода, дать комментарий к его содержанию. Bblboдbl. Документ представляет собой образец эпистолярного жанра со свойственными ему стилем, структурой, реквизитами, и введение его в научный оборот даст полезный материал для лингвистов. Также он будет интересен и для историков как документ, содержащий важную информацию об обстоятельствах ухода калмыков в 1771 г.
\end{abstract}

Ключевые слова: архивные документы, письмо, нойон Замьян, наместник, владельцы, астраханский губернатор, предупреждение, уход калмыков, причины ухода

Благодарность. Исследование проведено в рамках государственной субсидии проект «Устное и письменное наследие монгольских народов России, Монголии и Китая: трансграничные традиции и взаимодействия» (номер госрегистрации: AAAA-A19-119011490036-1). 
Для цитирования: Гедеева Д. Б. Письмо нойона Замьяна астраханскому губернатору Н. А. Бекетову о планах ухода калмыков на историческую родину // Монголоведение. 2020. T. 12. № 2. C. 244-254. DOI: 10.22162/2500-1523-2020-2-244-254

UDC 811.512.37

DOI: $10.22162 / 2500-1523-2020-2-244-254$

\title{
Disclosing Plans of Kalmyk Exodus to Ancestral Lands: Noyon Zamyan's Letter to Astrakhan Governor N. A. Beketov
}

\section{Daria B. Gedeeva ${ }^{1}$}

\author{
${ }^{1}$ Kalmyk Scientific Center of the RAS (8, Ilishkin Str., Elista 358000, Russian \\ Cand. Sc. (Philology), Leading Research Associate \\ iD 0000-0002-8735-9184. E-mail: dgedeeva@mail.ru \\ (C) KalmSC RAS, 2020 \\ (C) Gedeeva D. B., 2020
}

\begin{abstract}
Introduction. The article introduces a 18th-century archival document - letter addressed by Kalmyk Noyon (Landlord) Zamyan to the Governor of Astrakhan N. A. Beketov. Materials. The study examines an archival document contained in the National Archive of Kalmykia (Collection И-36). Results. The letter reports the then sentiments of Kalmyk nobility preceding the mass exodus of 1771 to ancestral lands. Surrounded by peoples differing in religion, language and traditions, the Kalmyks naturally kept identifying themselves as Asians and never gave up the idea of return, the latter having been strengthened by active colonizing policies of Russian government. Still, not all intended to leave the newly inhabited areas for a dangerous journey towards the unknown. And one of such individuals was Noyon Zamyan. His letter to the Governor expresses anxiety and wish to prevent Kalmyks from migrating backwards with the aid of Russian authorities. And more than that, the author explains why the people want to leave Russia's borders. This precious historical document is also an essential linguistic source on mid-to-late 18th-century Kalmyk language. Conclusions. The document is a typical sample of official epistolary writing in terms of style, structure, and other details, serving a useful source for further linguistic research. It also contains important information related to actual circumstances of the 1771 exodus, and may be of certain interest for historians.
\end{abstract}

Keywords: archival documents, letter, Noyon Zamyan, viceroy, landlords, Astrakhan governor, warning, Kalmyk exodus, reasons of migration

Acknowledgements: The reported study was funded by government subsidy — project name 'Oral and Written Heritage of Mongolic Peoples of Russia, Mongolia and China: CrossBorder Traditions and Interactions' (state reg. no. AAAA-A19-119011490036-1).

For citation: Gedeeva D. B. Disclosing Plans of Kalmyk Exodus to Ancestral Lands: Noyon Zamyan's Letter to Astrakhan Governor N. A. Beketov. Mongolian Studies (Elista). 2020. Vol. 12. No. 2. Pp. 244-254. (In Russ.) DOI: 10.22162/2500-1523-2020-2-244-254 


\section{Введение}

Введенные в научный оборот памятники деловой письменности дают лингвистам новый материал для диахронического изучения языка. Их тексты, содержащие к тому же ценный исторический материал, интересны также и для тех, кто изучает историю народа. Поэтому представленное нами в данной статье письмо нойона Замьяна, написанное 28 февраля 1767 г. астраханскому губернатору Никите Афанасьевичу Бекетову о готовящейся перекочевке калмыков на территорию исторической родины, будет представлять интерес как для лингвистов, так и для историков. Конечно же, этот документ уже рассматривался узким кругом ученых, изучавших причины ухода калмыков в 1771 г., однако широкому кругу читателей и исследователей его текст не известен.

Обстоятельства ухода народа с территории России изучаются учеными, но еще в большей степени они обсуждаются в народе. Почему ушли, почему не все? Почему так произошло, что разделились, ведь это для немногочисленного народа было крайне нежелательно. Исчерпывающие ответы на эти вопросы должны дать историки, работающие с архивным материалом того времени. Общий круг проблем, явившихся причиной ухода калмыков, ими уже очерчен и освещен в их многочисленных статьях и монографиях [Цюрюмов 2001; Цюрюмов 2003; Дорджиева 2002; Колесник 2003; Батмаев 1993].

Мы, со своей стороны, решили ввести в научный оборот текст упомянутого выше письма и написать небольшой комментарий к его содержанию. Документ представляет собой памятник калмыцкой деловой письменности XVIII в. и является ценным источником для лингвистов. Для изучающих историю языка старописьменный текст важен как объект изучения, а для широкого круга читателей - как калмыцкая речь, дошедшая на письме до нас через века.

Вертикальное письмо, красивое по форме и гармоничное по своим орфографическим правилам, также важно для изучения и демонстрации письменной культуры народа. Поэтому в статье приводится факсимиле старописьменного документа, транслитерация текста, переложение его на современный калмыцкий язык и русский перевод того времени, переложенный на современную графику.

\section{Исторический комментарий}

Письмо, написанное в начале 1767 г., за четыре года до ухода калмыцкого народа, свидетельствует о том, что план его осуществления уже зрел в умах калмыцкой элиты, однако не было благоприятных условий для его воплощения.

Нойоном были написаны несколько писем губернатору в разные годы, в которых он делился своими подозрениями о планах некоторых калмыцких нойонов увести народ из России. Подозрения у него основывались на слухах и собственных наблюдениях. Так, в письме от 24 марта 1765 г., за шесть лет до перекочевки, он пишет: ibān xariudtān manayidu irebe. keleqsen ügeni maniyigi yuun-du ebdeneyiči manā neyile. ese niyileküne beyeyinēn sai bederelcekü bida.. ${ }^{l}$

\footnotetext{
1 Здесь и далее в тексте транслитерации встречаются знаки в виде одной и двух точек, которые передают знаки препинания в калмыцком вертикальном письме. С позиций современной пунктуации можно считать их и запятой, и точкой.
} 


\section{Источниковедение}

čimadu adali orosiyin oyiro suuxu mani ügei. küüriyin sonosusu gēd arki yekede ögüleyibi. soqtudān keleqsen ügeni ene. zöb buruugiyin medekü bišibi. tandu sonosxuxuyin tölödü bičibebi (Иван хәрүдтән манад ирв. Келсн үгнь: «Маниг юунд эвднәч? Манла ниил. Эс ниилхлә бийинән сә бедрлцхвидн. Чамд әдл орсин өөр суушговидн». Күүринь соңссу гиһәд, әрк икәр өгләв. Согтудан келсн үгнь эн, зөв буруһинь медхшв. Танд соңсххин төләд бичвв) 'На обратной дороге к нам заехал [зайсанг] Иван. Он сказал: «Зачем ты вносишь раскол среди нас? Присоединяйся к нам. Если не хочешь присоединиться, мы сами будем искать [без тебя] для себя лучшее. Мы возле русских, как ты, жить не будем». Чтобы послушать его, я дал ему побольше арки. Не знаю, истинные или неистинные слова были им сказаны, когда он был пьян. Пишу, чтобы донести это до Вас' [НА РК. Оп. 1. Д. 368. Л. 413 (8)].

В феврале 1769 г. он снова пишет о своих подозрениях: nayimasliq ubašadu sanājān keleqsen kümün cevaq. yerenpel. lobzang gyalcan. raši donrub. geldei.

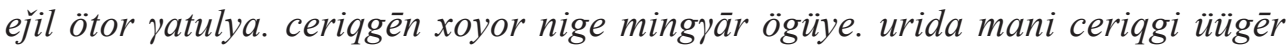
aba. bida čigi ögö. gēd bayiya. üügēr ese bolxuna. xasaqgi dobtolōd kitad tala nüüye gekü küür kelèd.. ene ügeyin zöb geqsen-dēn übülēr nüügēd ejil-dü šidar irebe. <..>> ezeni üyiledü muи bolultai gēd. zam dbyangs. gübernatortu küüneǰ bičibe (Нәәмслг Увшд санаһан келсн күмн - Цевг, Еремпл, Луузң Жалцн, Даш Дондук, Гелдә. «Өтр һатлйа. Цергән хойр нег миңһәр өгйә. Урд мана цергиг үүгәр ава, бидн чигн өгә гиһәд бәәйә. Үүгәр эс болхна, хасгиг довтлад, китд тал нүүйә», - гих күр келәд, Эн үгин зөв гисндән үвләр нүүһәд, Ижлд шидр ирв. <..> Эзнә Үүлд му боллта гиһәд Замьяң губернаторт келж бичв) 'Люди, которые сказали наместнику о своем намерении, это Цебек, Еремпель, Луузанг Джалцан, Даши Дондук, Гелдей. Они сказали: «Давайте срочно переправляться [через Волгу]. Войска [на войну] дадим одну-две тысячи. Скажем, что раньше в таком количестве у нас брали, и мы в таком количестве их давали. А если так не получится, нападем на казахов и уйдем в Китай». В подтверждение этих слов они зимой подошли к Волге. Подумав, что это для государственного дела нехорошо, [я] Замьян написал об этом губернатору' [НА РК. И-36. Оп. 1. Д. 418. Л. 3].

Раскрытие этого сговора закончилось бы для владельцев-организаторов драматично, если бы российские власти приняли во внимание информацию нойона Замьяна и поверили ей. В любом случае мы можем только предполагать об истинных мотивах нойона: то ли это беспокойство за дела российские, то ли выражение враждебных чувств к наместнику.

То, что Замьян пользовался слухами и не был посвящен в план действий, свидетельствует о том, что уходить собирались не всем народом, а только с единомышленниками, к которым нойон Замьян не относился. Известно, что у него отношения с наместником были недружественные. Как он пишет 28 декабря 1769 г. губернатору: nayimaslaq. axatai yerü xalmiq. nada dura ügei boldoqni. mamayigi orostu sayin oros ger bariulba gēd dura ügei boldoq.. (нәәмслг ахта йирин хальмг нанд дурго болдгнь - намаг орст сән, орс гер бәрүлв гиһәд дурго болдг) 'обычные калмыки во главе с наместником не любят меня, говорят, что я к русским склонен и заказал им построить себе русский дом’ [НА РК. Оп. 1. Д. 421. Л. 18-18 об.]. 
В публикуемом нами письме от 28 февраля 1767 г. нойон сообщает, что бывших ханов не покидала мысль вернуться к себе на историческую родину. По его словам, Аюка-хан пытался дважды уйти и не смог этого сделать. Замысел этот не смогли осуществить также ханы Дондук-Омбо и ДондукДаши, отец Убаши. И нойон Замьян не верит в счастливый исход этого опасного мероприятия и считает, что если предыдущим ханам это не удалось: odō üčüüken edendü zokixuyin medekü bišibi (ода үчүкн эднд зокхинь медхшв) 'то в настоящее время этим малосильным пойдет ли это на пользу' [НАРК. И-36. Оп. 1. Д. 418. Л. 26-26 об.].

Нойон в письме перечисляет причины, по которым наместник и его окружение хотят уйти из-под власти российского государства под покровительство Китая: они уходят туда, где находится истинная родина дербен-ойратов; китайцы и калмыки являются единоверцами; Тибет, где находится их духовный учитель, расположен рядом; китайский император отличается своей щедростью к своим подданным. Из этих высказываний нойона можно сделать вывод о том, что одними из основных причин ухода калмыков в 1771 г. явилось чужое для них по вероисповеданию и традициям окружение; большое расстояние, отделяющее их от духовного учителя, недостаточное вознаграждение калмыков от российского правительства за их участие в многочисленных войнах, боевых операциях. Конечно, Замьян не пишет об этих и многих других причинах дискомфорта, которые стали испытывать со временем калмыки на новой территории: контроль и ограничение самостоятельности, людские потери в частых российских войнах, христианизация калмыцкого населения, колонизация калмыцких территорий, жесткое российское судопроизводство, неприемлемое для свободолюбивых кочевников и др. [Цюрюмов 2000; Дорджиева 2002; Колесник 2003; Орлова 2006; Батмаев 2009; Очиров 2009; Гедеева, Гэрэлма Гёрёчин 2019].

Нойон считает, что калмыки уподобились гибкому дереву, которое под тяжестью урожая яблок ломается, сравнивая яблоки с щедротами государыни.

\section{Письмо нойона Замьяна астраханскому губернатору}

\section{Н. А. Бекетову от 28 февраля 1767 г.}

\section{Транслитеращчия}

dēdü yeke imparātoricayin nige züqgiyin üyileyin dān kēji yosbodiyin genaral mayuur kabilar ayisdarxani gübērni gubernator nikita aponās yāči beke tob-tu.

yerü mandu adali ulus dēdü imparātoricayin. yeke. dunda. ücüüken ene yurban öröšōldü kürteqsen albutu tōtu. amin andaүārān ese ögüqsen kümün ügei bišuyu. xaǰigir sanā ügei ezeni üyiledü amin biyēn nōl ügei ögüye geǰi andayār kesen bišuyu. tere üyileyigi xadayallaqsan kümün yosun biši üyile keseyigi küünekü kereqtei biyiza gēd ene züqgiyin üyileyigi niqta dān keǰi bayixu tandu. andarai borōniyigi tandu angxarya geleyibi ünen xudaliyin nayimaslaqgiyin oyiro yabudaq abicarmuud meden gesen biyiza medebečigi xotuyin küčir ülü meden gekü biyiza. tani zergedü bayixuyin xoyi medeqdenei. yerü ene zöb geǰi šiyidči kelelceqsen kümün. bambar. cevaq. šēreng. vinraq. busaraman genei. 


\section{Источниковедение}

sayin kümünēse orolcoqson kümün. raši donrob. lubzang gyalcan. šarabiyin köböün

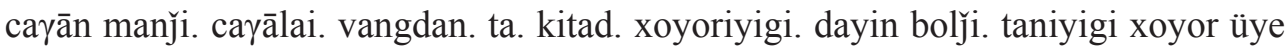
kitad dayilaldād daruǰi. ene zanggiyigi elči oduqsun. don rub byamcuu. bičij̄i ilgeǰi. kitadiyin ceriq oriyin yaqca modondu ireǰi geǰi sonosōd. urida don rub rašiyin caqtu yabudaq axaš gedeq küyigi ilgeǰi oron bortu tere ceriq ünen bolxuna. ceriqtüni oroji ögüye geǰi šiyidči. ceriq ügei bolbočigi bi yazarčilasubi geǰi šēreng keleji ünen xudaliyin medekü bišibi. miniy sonosuqsan ene yerü yuun geji iyigeji duralanai gemeqce. dörbön oyirod gedeqgiyin nutuq tere bolunai. nige dügērtü nom nigetei kitad

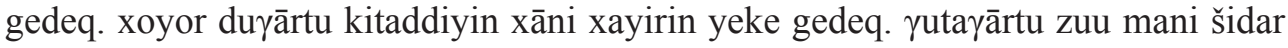
gedeq. yerü urida ayuuki xān xoyor üye nüüji yadād bayiqsan. tüüni xoyino don rub vangbu sedbečigi tere sanāni biyedüni zolkis ügei bolulai. töüni xoyino don rub daši sanabačigi basa ese bütülei. odō üčüüken edendü zokixuyin medekü bišibi. yerü ene ünen bolxuna tenggeri metü yeke imparātoricayin öröšöl xayiri dāji yadād biyidēn

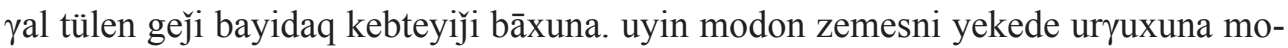
doni biyeni xuүuranai geqčidü adali kebtei bolxuǰibāxuna. yerü ene üge dēre nada bičiqsen ügeyin šinǰilen medekü ülü bayinta. yere ene sonosuqsan üge mini nada kereq ügei üge ünen bolxuna tandu ezeni üyiledü kereqtei biyiza gēd yaryaǰi keleqsen üge mini ene. yerü ene ügei mini yerü kümün-dü bitegei medeqdüyita. cori yaqcaxan andarai borōnin medeqsen. andarayi bitege bičiülüqtün. tere ulus medeküne nada medeqdel ügei bayixu ügei bolxu.. tanai xayirlaǰi bayixudu ünen sonosoqsan ügēn zam dbyangs. bičǐ̌i bariulba.. tani delgürünggügēr bičiji öq gesen ešīr bičibe..

\section{Переложение на современный калмыцкий язык}

Деед ик императрицан нег үзгин үүлин дан кеж господин генерал майур кавлр Әәсдрхнә гүбернә губернатор Никита Апонасйач Бекетовт.

Йирин манд әдл улс деед императрицан ик, дунд, Үчүкн - эн һурвн өршәлд күртсн алвт тоот әмн андһаран эс өгсн күмн уга бишү.

Хажһр сана уга эзнә үүлд әмн бийән нөөл уга өгйә гиж андһар кесн бишйү. Тер Үүлиг хадһлсн күмн йосн биш үүл кесиг келх кергтә бииз гиһәд, эн үзгин ҮҮлиг нигт даан кеж бәәх танд Андра Ворониг танд аңхрһ гиләв. Үнн худлын нәәмслгин өөр йовдг авицармуд медн гисн вииз. Медвчигн, хотын күчәр эс медн гих вииз. Таниг зергд бәәхин хөөһүр үүнд бәәгч нойдудыг андһаринь эс авсн нойн эс медгднә.

Йирин эн зөв гиж шиидч келлцсн күмн - Бамбр, Цевг, Шеерң, Бусрмн гинә. Сән күмнәс орлцсн күмн Даш Дондук, Луузанг Жалцн, Шарвин көвүн Цаһан Манж, Цаһала, Ваңдн.

Та китд хойриг дән болж, таниг хойр үй китд дәәллдәд дарж. Эн зәңгиг элч одсн Дондук Жамцу бичж илгәж. Китдин церг Орин һагц Моднд ирж гиж соңсад, урд Дондук-Дашин цагт йовдг Ахш гидг күүг илгәж. Орн Борт тер церг үнн болхла, цергтнь орж өгйә гиж шиидж. Церг уга болвчигн, би һазрчлсв гиж Шеерң келж. Үнн худлинь медх бишв. Мини соңссн эн.

Йирин юн гиж иигж дурлна гихлә - дөрвн өөрд гидгин нутг тер болна. Негдүгәрт, ном негтә китд гидг. Хойрдуһарт, китдин хаана хәәрн ик гидг. Һутаһарт, Зу мана - шидр гидг.

Йирин урд Аюка хаан хойр үй нүүж ядад бәәсн. Түүнә хөөн Дондук-Омбо седв чигн, тер санань бийднь зокс уга болла. Түүнә хөөн Дондук-Даши санв 


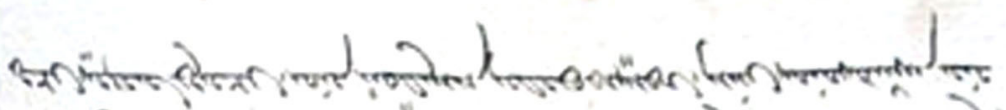

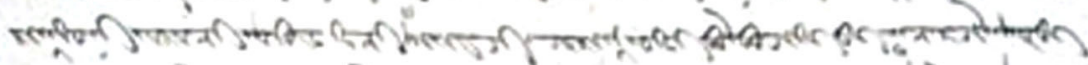

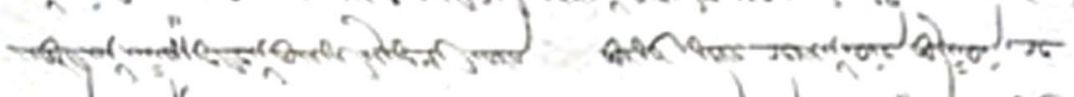

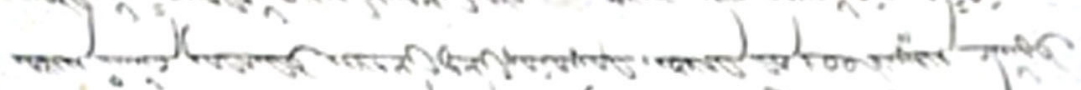

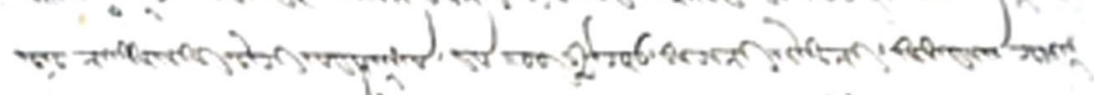

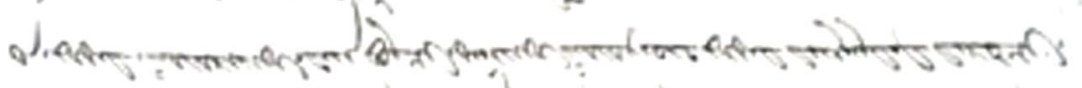

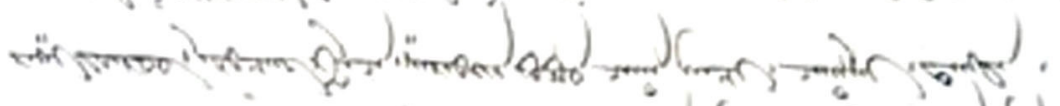

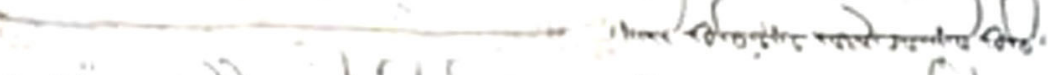

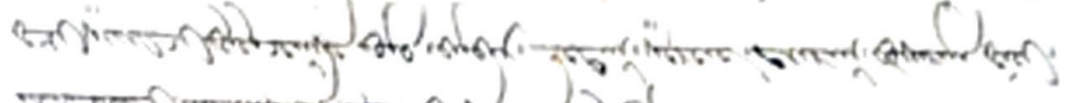

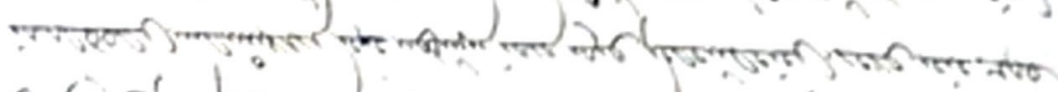

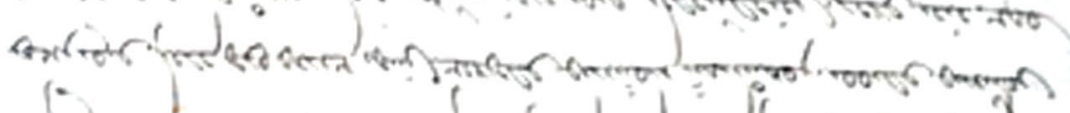

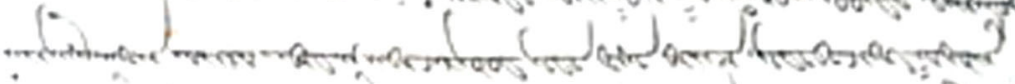

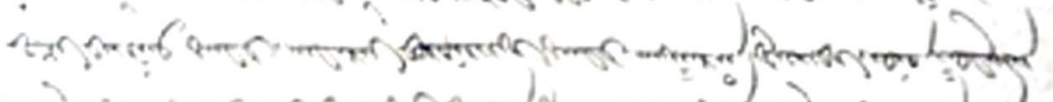

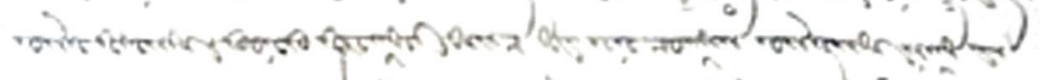

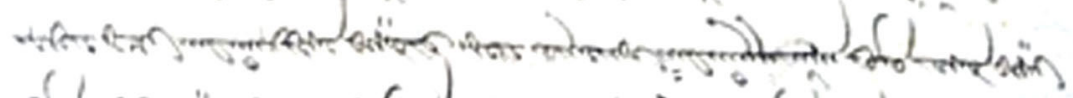

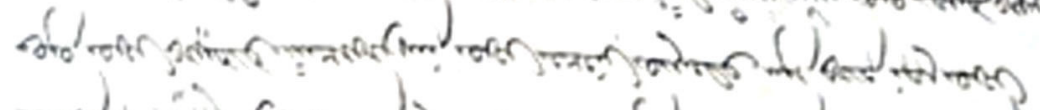

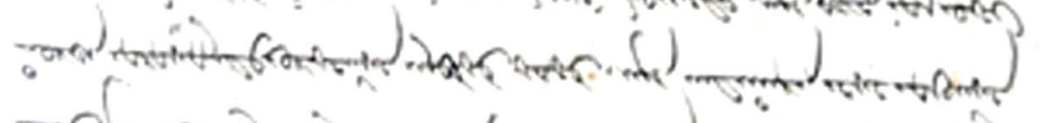

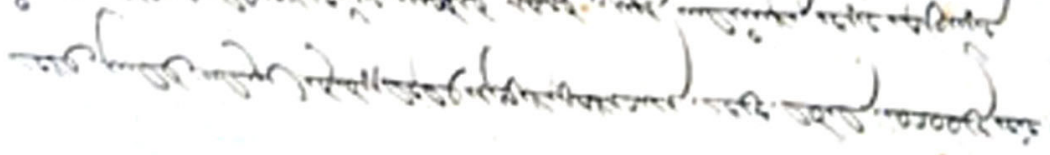

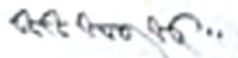

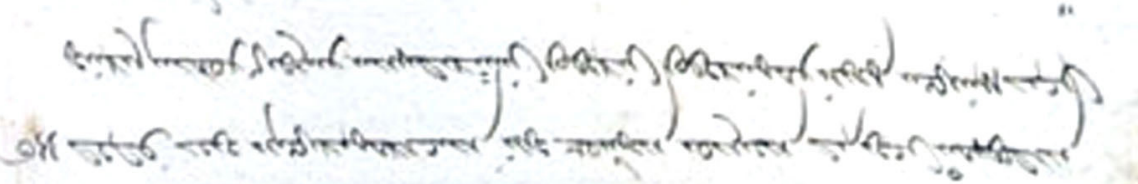




\section{Источниковедение}

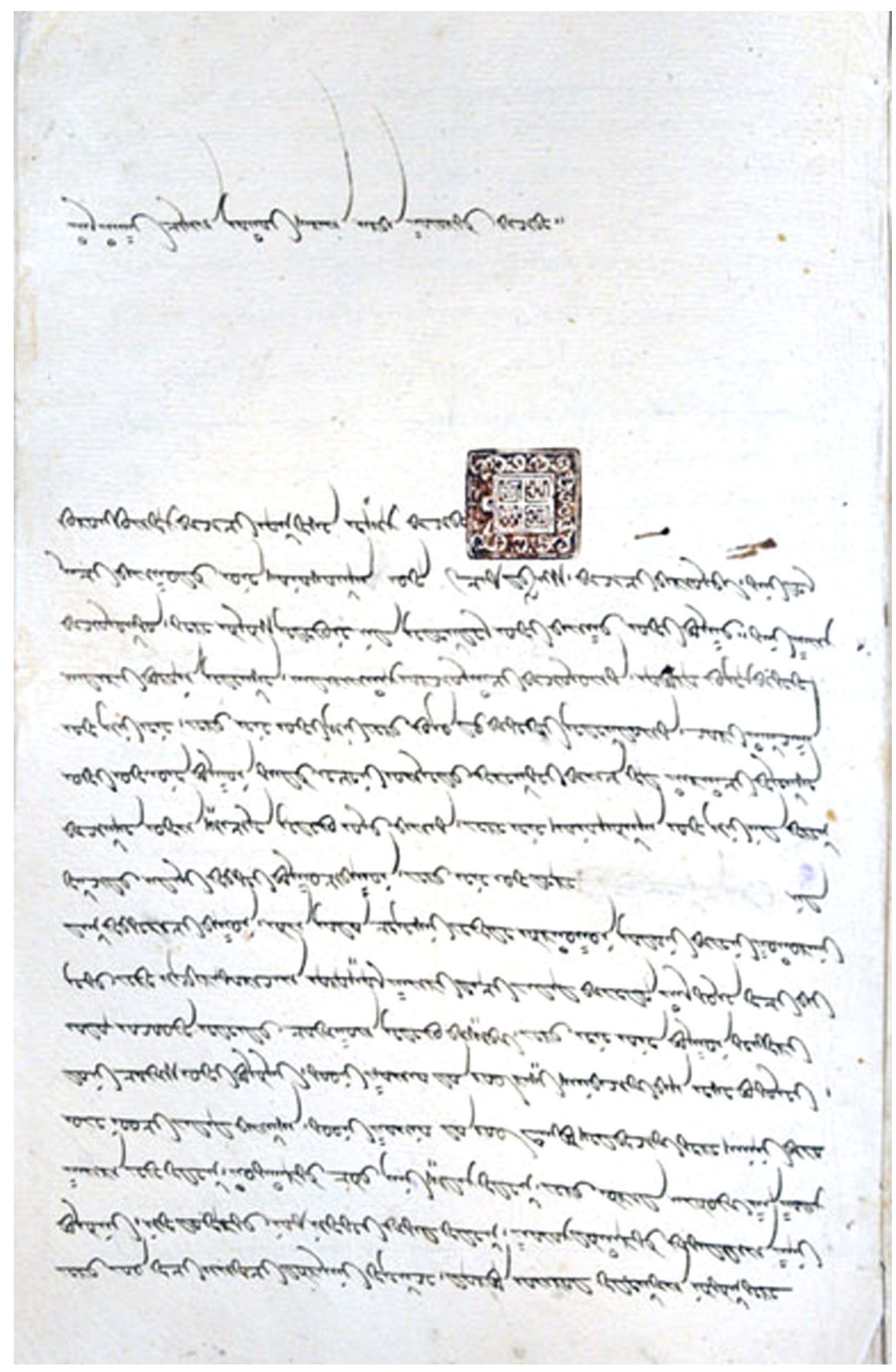

Факсимиле письма нойона Замьяна астраханскому губернатору Н.А. Бекетову от 28 февраля 1767 г.

Facsimile. Noyon Zamyan's Letter to Astrakhan Governor N. A. Beketov of February 28, 1767 
чигн бас эс бүтлә. Ода үчүкн эднд зокхинь медхшв. Йирин эн үнн болхла, теңгр мет ик императрицан өршәл хәәр дааж ядад, «бийдән һал түлн» гиж бәәдг кевтәжхн. «Уйн модн земснь икд урхна, модна бийнь хуһрна» гигчд әдл кевтә болхжхн.

Йир эн үг деер «...(текст стерт)» нанд бичсн үгинь шинжлн медх эс бәәнтә. Йир эн соңссн үгм нанд керг уга үг, үнн болхла танд эзнә үүлд кергтә бииз гиһәд, hарһж келсн үгм эн. Йир эн үгим йирин күмнд битгә медүлт. Цөр һагцхн Андра Боронин медсн. Андраһар орчулж бичүлитә. Өвр кумәр битгә бичүлтн. Тер улс медхлә, нанд медгдл уга бәәшго болх. Танаг хәәрлж бәәхд үнн соңссн үгән Замъян бичж бәрүлв. Тана делгрүңгүһәр бичж өг гисн эшәр бичв.

\section{Переложение русского перевода 1867 г. на современную графику}

Перевод с писма калмыцкаго представленнаго Его Превосходителству господину генерал майору ковалеру и астраханскои губерни губернатару Никите Афонасьевичю Бекетову от калмыцкаго владелца Замъянга марта 2 дня 1767 года.

\section{Потитуле}

Понеже нет такого из по оказанной ея императорскаго величества в высочаишеи милости содержащаго народа которыя бы верно в нещадности живота своего присягою небыли обязаны и скоих признавая я себя почел задолгу мои о уведонном мною непристоином деле яко по веренной вовсем в здешней губерни персоне вам донесть о каковых обстоятельствах уповаю и определенным при наместнике афицерам небызызвестно или может что они по какому либо пристрастию не хотят о том и ведать. В отсудствие ваша когда вы были при дворе я не знаю от котораго с владелца присяги было не взято, а именно из владельцов от Бамбара, Цебека, Шеаренга, Яндыка и Босурмана також и из знатных заисангов при том в едино согласии были Даши Дондук, Лозонг Джалчин, Цаган Манджи Шарапов, Цагалай Иондон, а учиненная их присяга состояла в том, в бытность в Санкт Петербурге посланец их Дондук Джамцо чрез писмо свое дал им знать что якобы с Россией китаицы имеют войну и будто двое кратно китаицы над россииским воиском одержали победу, и китайское де воиско уже состоит при Ор реке, где есть одно древо, по которым известиям отправлен был от них до Оренбурга калмыченин Ахаш которои служил еще при Дондук Даше: для получения в том достовернаго сведения и остались они с таким пред приятием, ежели воиско китаиское деиствительно в тех местах продолжаетца, то б отсюда уклонитца под их защищение в протекцию, а хотя ж от войска и там не было то ив таком случае чтоб выитти туда под предводителством Шеаренга которым выводом онои Шеаренг их и уверил, а правда ли все то или нет не знаю, причинаже таковому их воспринятому намерению во-первых та что дербен оиродов природное тамо место, а паче потому что китаицы однозаконцы при том же слышно о китаиском хане что он к подданным оказывает великие милости, к томуж и Зу калмыцкое оттуда недалеко. Но при всем том я как небезызвестен что на пред сего предки наши бывшие ханы во первых Аюка имел двое кратное намерение отсюда туда откочевать, но того учинить не удалось, а потом и Дондук Омбо такое же намерение к ползе ево не послужило, якоже потом на последок в 


\section{Источниковедение}

таковом же пред приятии и Дондук Даше удачи не было, а ныне чтоб оным будучи в мало силии своем намерение их послужило я о том не понимаю и буде такое их пред приятие в истинную, то не иначе разуметь, что они подобнои богу Ея величества Государнину излианную к ним щедрую милость не могли снесть и почтя ту тяжелым себе игом яко наложением наших (?) огня и дров, чем все оныи и заслуживают примеру зыблящему древу приносящему много плодия и неснещему того плода по отламывающему вы можите приметить об обстоятелствах сих и исприсланаго от Бамбара ко мне писма, и так о всем оном ежели то правда почел я что надлежало известну быть о сем при делах государниных а не у меня, для чего сие вам и открываю только с тем, дабы никто о сем моем представлении сведом не был, а как о сем ныне кроме переводчика Воронина никто не знает, почем и прошу приказать оное ему и перевесть а другому никому не отдавать, а ежели сие наружу выдет, то мне безызвестно быть не неможет. И так я Замъянг в разсуждении ко мне вашеи милости действительно о слышанном мною чрез сие как и повелено указом вам представить неприминул, писано февраля 28 дня 1767 года. У писма Печать [НАРК И-36. Оп. 1. Д. 418. Л. 26-26 об.].

\section{Выводы}

Рассматриваемый документ представляет собой образец эпистолярного жанра, и введение его в научный оборот даст ценный материал для лингвистов. Также он будет интересен и для историков как документ, содержащий важную информацию об обстоятельствах ухода калмыков в 1771 г. Публикация подобных документов знакомит исследователей и широкий круг читателей с подробностями жизни калмыков несколько столетий назад. Это необходимо современному поколению, чтобы продолжать славные традиции народа, задуматься о трагических страницах его истории, а лидерам нации чтобы оберегать свой народ от физического и материального упадка и помнить, что территория является базой для сплочения всего народа во имя ее процветания.

\section{Источники}

НА РК — Национальный архив Республики Калмыкия.

\section{Литература}

Батмаев 1993 - Батмаев М. М. Калмыки в XVII-XVIII веках. В 2 кн. Элиста: Калм. кн. изд-во, 1993. $381 \mathrm{c.}$

Батмаев 2009 - Батмаев М. М. Уход большей части калмыков в Джунгарию // История Калмыкии с древнейших времен до наших дней. В 3 т. Т. 1. Элиста: ИД «Герел», 2009. С. 420-431.

Гедеева, Гэрэлма Гёрёчин 2019 - Гедеева Д. Б., Гэрэлма Гёрёчин. Письмо пяти судей как источник для изучения судопроизводства калмыков в ХІХ в. // Монголоведение. 2019. № 2. C. 240-256. DOI: 10.22162/2500-1523-2019-2-240-256

Дорджиева 2002 - Дорджиева Е. В. Исход калмыков в Китай 1771 г. Ростов н/Д: СКНЦ ВШ, 2002. 212 c.

Колесник 2003 - Колесник В. И. Последнее великое кочевье. Переход калмыков из Центральной Азии в Восточную Европу и обратно в XVII и XVIII веках. М.: Вост. лит., 2003. 286 с. 
Орлова 2006 - Орлова К. В. История христианизации калмыков: середина XVII - нач. ХХ в. М.: Вост. лит., 2006. 205 с.

Очиров 2009 - Очиров У. Б. Участие калмыков в войнах в 1721-1771 гг. // История Калмыкии с древнейших времен до наших дней. В 3 т. Т. 1. Элиста: ИД «Герел», 2009. С. 420-431.

Цюрюмов $2000-$ Цюрюмов A. В. Участие калмыков в русско-турецкой войне 1768 1774 гг. // Вестник Калмыцкого государственного университета. Сер. «История, экономика, право». Элиста: КалмГУ, 2000. Вып. 1. С. 22-29.

Цюрюмов 2001 - Цюрюмов А. В. О причинах откочевки калмыков в Китай в 1771 году // Россия, Сибирь и Центральная Азия: взаимодействие народов и культур. Мат-лы ІІІ Междунар. науч.-практ. конф. Барнаул: АГУ, 2001. С. 10-15.

Цюрюмов 2003 - Цюрюмов А. В. Откочевка калмыков в 1771 году: фактор Тибета // Буддизм в контексте истории, идеологии и культуры Центральной и Восточной Азии. Улан-У дэ: Изд-во Бурят. науч. центра СО РАН. 2003. С. 7-8.

\section{Sources}

National Archive of the Republic of Kalmykia. Coll. И-36. Cat. 1. Files 368, 418, 421. (In Russ. and Kalm.)

\section{References}

Batmaev M. M. Kalmyks in the $17^{\text {th }}-18^{\text {th }}$ Centuries. In 2 vols. Elista: Kalmyk Book Publ., 1993. 381 p. (In Russ.)

Batmaev M. M. Exodus of the bulk of the Kalmyks back to Dzungaria. In: Ochirova N. G., Maksimov K. N. (eds.) History of Kalmykia: from Earliest Times to the Present Days. Ochirov U. B., Bakaeva E. P., Mitirov A. G. et al. In 3 vols. Vol. 1. Elista: Gerel, 2009. Pp. 420-431. (In Russ.)

Dordzhieva E. V. The 1771 Kalmyk Exodus to China. Rostov-on-Don: North Caucasus Scientific Center (Southern Federal University), 2002. 212 p. (In Russ.)

Gedeeva D.B., Guruuchin G. The letter of five judges as a source for studies of $19^{\text {th }}$-century judicial proceedings of the Kalmyks. Mongolian Studies. 2019. No. 2 (17). Pp. 240-256. (In Russ.) DOI: 10.22162/2500-1523-2019-2-240-256

Kolesnik V. I. The Last Great Migration: Resettlement of Kalmyks from Central Asia to Eastern Europe and Backwards in the $17^{\text {th }}$ and $18^{\text {th }}$ Centuries (Respectively). Moscow: Vostochnaya Literatura, 2003. 286 p. (In Russ.)

Ochirov U. B. Participation of Kalmyks in wars (of Russia): 1721-1771. In: Ochirova N. G., Maksimov K. N. (eds.) History of Kalmykia: from Earliest Times to the Present Days. Ochirov U. B., Bakaeva E. P., Mitirov A. G. et al. In 3 vols. Vol. 1. Elista: Gerel, 2009. Pp. 420-431. (In Russ.)

Orlova K. V. Christianization of Kalmyks: Chronicles, Mid-17 th to Early $20^{\text {th }}$ Centuries. Moscow: Vostochnaya Literatura, 2006. 205 p. (In Russ.)

Tsyuryumov A. V. Kalmyks in the Russo-Turkish War of 1768-1774. Bulletin of Kalmyk University. 2000. No. 1. Pp. 22-29. (In Russ.)

Tsyuryumov A. V. The 1771 Kalmyk exodus to China: reasons revisited. In: Russia, Siberia and Central Asia: Interaction of Peoples and Cultures. Conf. proc. Barnaul: Altai State University, 2001. Pp. 10-15. (In Russ.)

Tsyuryumov A. V. The 1771 Kalmyk exodus: the factor of Tibet. In: Buddhism in the Context of Central and East Asian History, Ideology, and Culture. Ulan-Ude: Buryat Scientific Center (Sib. Branch) of RAS 2003. Pp. 7-8. (In Russ.) 